\title{
The Effect of Plyometric Training in Volleyball Players: A Systematic Review
}

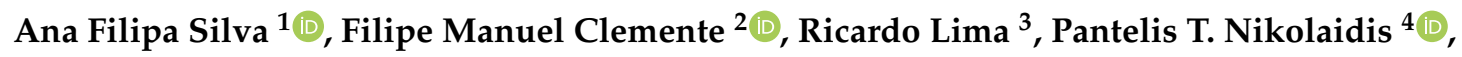 \\ Thomas Rosemann ${ }^{5}$ and Beat Knechtle ${ }^{6, *(D)}$ \\ 1 Polytechnic Institute of Viana do Castelo, School of Sport and Leisure, 4960-320 Melgaço and Research \\ Nucleos of Polytechnic Institute of Maia (N2i), 4475-690 Maia, Portugal \\ 2 Polytechnic Institute of Viana do Castelo, School of Sport and Leisure, \\ Melgaço and Instituto de Telecomunicações, Delegação da Covilhã, 6200-001 Covilhã, Portugal \\ 3 Polytechnic Institute of Viana do Castelo, School of Sport and Leisure, Melgaço, \\ CIDESD-The Research Center in Sports Sciences, Health Sciences and Human Development, \\ 4960-320 Melgaço, Portugal \\ 4 Exercise Physiology Laboratory, Nikaia 18450, Greece \\ 5 Institute of Primary Care, University of Zurich, Zurich 8091, Switzerland \\ 6 Medbase St. Gallen Am Vadianplatz, St. Gallen 9001, Switzerland \\ * Correspondence: beat.knechtle@hispeed.ch; Tel.: +41-(0)-71-226-9300
}

Received: 8 July 2019; Accepted: 15 August 2019; Published: 17 August 2019

\begin{abstract}
Volleyball is considered a very explosive and fast-paced sport in which plyometric training is widely used. Our purpose was to review the effects of plyometric training on volleyball players' performance. A systematic search was conducted according to the preferred reporting items for systematic reviews and meta-analyses (PRISMA) guidelines using PubMed, SciELO, SPORTDiscus, Medline, Scopus, Academic Search Complete, CINAHL and Web Science for articles published no later than December 2018. Any criteria were imposed for the included sample. The search focus was on interventional studies in which athletes underwent a plyometric program. To the 1831 articles found, another five were added, identified through other sources. Duplicated files were removed, titles and abstracts were screened, which left 21 remaining studies for extensive analysis. Results showed that the vertical jump ( 15 studies) was the major ability studied in plyometric training interventions, followed by strength (four studies), horizontal jump (four studies), flexibility (four studies) and agility/speed (three studies). In addition, it was observed that young (under 18 years old) female athletes were the most studied. The included studies indicated that plyometric training seems to increase vertical jump performance, strength, horizontal jump performance, flexibility and agility/speed in volleyball players. However, more studies are needed to better understand the benefits of plyometric training in volleyball players' performance.
\end{abstract}

Keywords: plyometrics; performance; jump; strength; flexibility; agility

\section{Introduction}

Volleyball is an intense anaerobic sport that combines explosive movements (i.e., in both vertical and in horizontal directions) with short periods of recovery [1-3]. Therefore, explosive strength, which is defined as the ability of an individual's neuro-muscular system to manifest strain in the shortest possible time [4], is considered a fundamental aspect of successful athletic performance (e.g., [5]). In fact, when speed and agility are combined with maximum strength, power is the outcome [6]. Muscular power enables a given muscle to produce the same amount of work in less time, or a greater magnitude of work in the same time, which is important for sprinting, jumping [7] and quick changes 
of direction [6]. Indeed, studies have shown strong relationships between power measures and vertical jump performance (e.g., [7-9]), suggesting that power influences vertical jumping performance [10].

A vertical jump is a complex movement that requires the coordination of several muscles in the trunk, arms and legs [11]. Knowing that each player performs more than 250 jumps in a volleyball match of five sets $[12,13]$, jumping ability has been identified as one of the key determining factors of high performance in volleyball [14].

In fact, several studies have shown that vertical jump test results are indicative of the performance level of an athlete (e.g., [15-18]). For example, Smith [17] found that vertical jump performance during spiking and blocking was greater in Canadian national volleyball players compared to the Canadian university volleyball players. Also, Ziv and Lidor [16], in a review concerning vertical jump in female and male volleyball players, noted that better-performing teams were comprised of players with high vertical jumps [19].

Jump training is commonly associated with plyometric training and, in particular, with drills that stress the musculotendinous unit [20-22]. In fact, de Villarreal [23] found that a combination of bodyweight plyometrics, including countermovement jumps, depth jumps and squat jumps, resulted in a $4.7 \%$ to $15 \%$ increase in vertical jump height. Nevertheless, this type of training increases neuromuscular coordination through training the nervous system [24], thus allowing the stretch-shortening cycle (SSC)—which is a lengthening movement (i.e., eccentric) quickly followed by a shortening movement (i.e., concentric) [20,24]— to react faster [25]. Additionally, because this training includes muscle lengthening, it may also improve flexibility, increase the amount of stored elastic energy in the muscles [26], stimulate more muscle units [27], result in higher (neural) firing frequency $[27,28]$ and improve joint proprioception $[29,30]$.

According to the concept of training specificity, the effective transfer of training adaptations occurs when the training exercises match the task (e.g., testing, competition; [31]). In volleyball, plyometric training involves jumping, hopping and bounding exercises as well as throws that are performed quickly and explosively [32,33]. Those movements are also related to the development of agility [34-36]. This capability is thought to be a reinforcement of motor programming through neuromuscular conditioning and the neural adaptation of muscle spindles, Golgi tendon organs and joint proprioceptors [34].

In addition, the athlete's age and sex should be considered when planning strength training programs. For instance, during adolescence, the changes that occur in muscular, neuronal and hormonal systems [37] due to the development related to puberty (namely the growth spurt) influence adolescents' abilities to execute movements [38]. Moreover, the female growth spurt occurs approximately two years earlier than the male growth spurt and reaches its plateau at 15-16 years of age, whereas males continue their growth spurt up to the age of 19-20 years [39]. Due to these changes in adolescence, it was found that female athletes had weaker quadriceps and hamstring muscles (even when normalized for body weight) in the adult stage when comparing to their male counterparts [40]. Those dissimilarities reflect the different ability to produce strength, influencing jumping performance and is reflected in the different motor pattern showed by the two sexes [40].

Although plyometric training has been widely used in volleyball, little scientific information is available to determine its possible benefits on the different components of performance. Following this, the aim of this systematic review was twofold: (i) To evaluate the efficacy of plyometric training programs on both male and female volleyball players, and (ii) to understand the effect of those programs based on players' age.

\section{Materials and Methods}

\subsection{Literature Search Strategy}

A systematic literature search was carried out in PubMed, SPORTDiscus, MEDLINE, Scopus, CINAHL Plus, Academic Search Complete, Web of Science and SciELO. The search was limited to 
original articles written in English published online no later than December 2018, which is when the search was conducted.

The words used in databases combined terms related to plyometric training (strength training OR power training OR plyometric training OR resistance training OR weight training OR complex training OR weight-bearing exercise OR eccentric training) and volleyball.

\subsection{Selection Criteria}

The process for screening articles followed the preferred reporting items for systematic reviews and meta-analyses (PRISMA) guidelines [41]. The inclusion criterion included interventional studies which provided a plyometric strength program in volleyball team sports and which used statistical analyses to quantify the association between the training implemented and its benefits regarding performance. No restrictions were imposed on the participant sample in terms of age, sex, playing level, playing experience, etc. Literature reviews, overviews, conference proceedings and both masters and Ph.D. thesis were excluded.

The abstracts of all the articles found were screened against the predefined selection criteria by the authors of the present study. Cases of disagreement were discussed among the researchers until a consensus was established. The same process was used to screen the full-text version of each article. Furthermore, a few relevant articles that were not found in the first literature search-possibly due to discrepancies in the terminology used to describe plyometric training-were included.

A risk of a bias within the studies was independently assessed by the two reviewers considering the topics of (i) a bias in selecting participants into the study; (ii) a bias in classifying interventions; (iii) a bias due to departures from intended interventions; (iv) a bias from missing data; (v) a bias in measurement of outcomes; and (vi) a bias in reporting outcomes selectively. Studies with a risk of bias in all categories were excluded from the review. Agreement between reviewers was tested using the Kappa index test that revealed a value of 0.89 , suggesting a very good agreement.

\subsection{Assessment of Methodological Quality}

Methodological quality was assessed using the STROBE Statement, which is a 22-item checklist considered essential for the accurate reporting of observational studies. This checklist includes a link between the title of the article and its abstract (item 1), introduction (items 2 and 3), methods (items 4 to 12), results (items 13 to 17) and discussion (items 18 to 21) sections, and any other information (item 22). From those, 18 items are common to all three designs, while four (items 6, 12, 14 and 15) are design-specific, with different versions for all or part of the item. For some items (indicated by asterisks), the information should be given separately for cases and controls in case-control studies, or for exposed and unexposed groups in cohort and cross-sectional studies. Each article was classified based on the sum of the points for all 22 items (one point was counted for an item if the criteria was achieved), and the result was divided by the maximum possible point total of 22 (e.g., if an article had 11 points, the value arrived at was 0.5 ).

The items of all articles were independently classified by each of the observers, and then an interobserver reliability analysis was conducted. The Kappa index test revealed a value of 0.94 (90\% IC: 0.92-0.96), indicating very good agreement between observers.

\subsection{Data Extraction and Analysis}

For the articles included in this study, all authors discussed how the information should be organized regarding the characteristics of the studies and the results of the assessed measurement properties. Afterwards, two independent reviewers extracted data regarding the participants' characteristics (i.e., number, age and skill level) and the results of the implementation of the plyometric training on the physical component(s) studied in each article (i.e., vertical jump, agility/velocity, strength, power, horizontal jump and flexibility). 


\section{Results}

\subsection{Search, Selection and Inclusion of Publications}

From the database search, 1381 files were found to which five more were added from other sources. These data were then exported to reference manager software (EndNote ${ }^{\mathrm{TM}} \mathrm{X} 8, \mathrm{Clarivate}$ Analytics, Philadelphia, PA, USA), and 314 duplicates were eliminated. The remaining 1072 files were screened for relevance according to their titles and abstracts; through this process, another 1016 articles were removed. After the full texts of the remaining 56 articles were read, another 24 were excluded due to a lack of relevance to the specific purpose of the current study. In the final step of the screening procedure, another 13 articles were eliminated either because they included other sports in their analysis $(n=2)$, added another strength methodology training $(n=9)$, studied the effect of training on postural control $(n=1)$ or indicated no experimental intervention $(n=1)$. After the entire screening process was complete, 19 files were deemed acceptable for inclusion in the present review. A schematic summary of this search is shown flowchart in Figure 1.

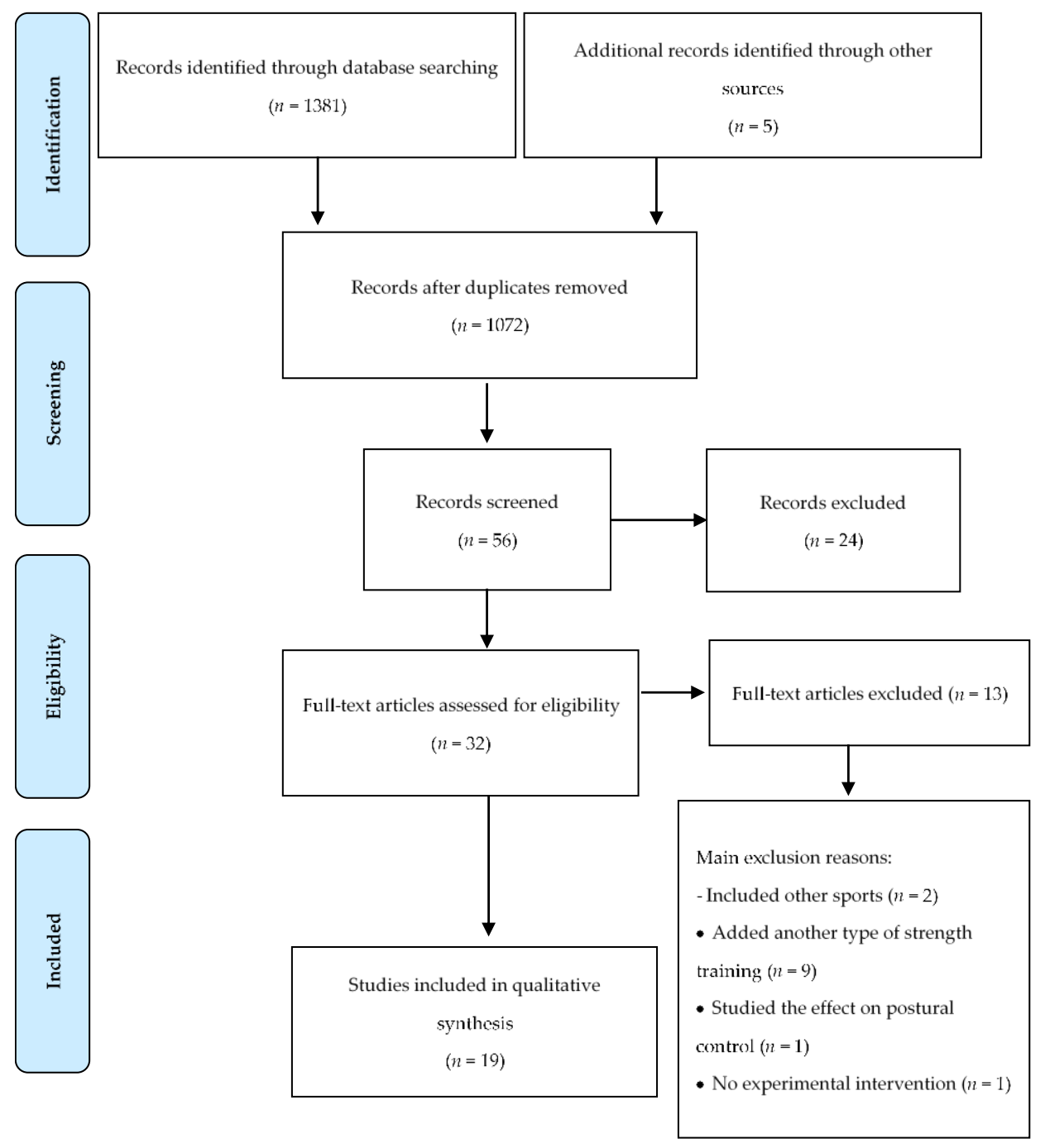

Figure 1. Flowchart on the literature search of plyometric training in volleyball.

\subsection{Studies Score}

Studies were evaluated through the STROBE scale and Table 1 presents the score achieved by each study. 
Table 1. Quality score for the included studies.

\begin{tabular}{cccc}
\hline Study & Quality Score & Study & Quality Score \\
\hline Martel, Harmer [42] & 0.55 & Turgut, Colakoglu [43] & 0.82 \\
Hewett, Stroupe [44] & 0.45 & Radu, Făgăraş [45] & 0.73 \\
Lehnert, Lamrová [46] & 0.36 & Hrženjak, Trajković [47] & 0.32 \\
Gjinovci, Idrizovic [48] & 0.77 & Trajkovic, Kristicevic [49] & 0.41 \\
Ramlan, Pitil [50] & 0.41 & Çankaya, Arabac1 [51] & 0.32 \\
Milić, Nejić [52] & 0.50 & Mroczek, Superlak [53] & 0.32 \\
Vassil and Bazanovk [54] & 0.27 & Bashir, SulehHayyat [55] & 0.41 \\
Idrizovic, Gjinovci [56] & 0.73 & Çımenl, Koç [57] & 0.41 \\
Myer, Ford [58] & 0.68 & Sheikh and Hassan [59] & 0.55 \\
Veličković, Bojić [60] & 0.55 & & \\
\hline
\end{tabular}

\subsection{Data Organization}

The data for the present study were grouped according to the effects of plyometric training on the different physical fitness components studied in volleyball players (i.e., vertical jump, strength, horizontal jump, flexibility and agility/speed). Each of the three authors of the present study independently classified the papers according to the different research topics (components). Disagreements were resolved through discussion among the three authors until a consensus was reached.

\subsubsection{Effects of Plyometric Training on Vertical Jump Performance}

Fourteen of the 19 articles included in this systematic review offered inferences about the effects of plyometric training on vertical jump performance (Table 2). The vertical jump tests used in these studies included the squat jump, countermovement jump, drop jump, standing vertical jump, single leg jump and repeated jumps (15 and $30 \mathrm{~s}$ ). Eleven of the 14 studies which reported data about the effects of plyometric training on vertical jump performance were exclusively conducted on women ranging from 14 to 22 years of age, most of which $(n=9)$ were conducted in under- 18 women players. No study tested the effects of plyometric training exclusively in men; two of the articles analyzed the effects of plyometric training in both men and women.

The training protocols varied between two and three training sessions per week, and the total intervention period ranged from four to 16 weeks. The most common protocols lasted $6(n=4)$ or $12(n=4)$ weeks. In all the studies, improvements in vertical jump performance were observed after the intervention. The plyometric training protocols varied, being carried out either on a traditional gymnasium floor, grass or concrete, while some studies included aquatic plyometric sessions. However, the most common setting was a traditional gymnasium floor. Frequently, training programs included both leg jumps, single-leg jumps, hurdle jumps, drop jumps, box jumps or lunge jumps. Ball throws were the most common upper-body exercise performed.

After a four-week-long aquatic plyometric training intervention conducted on under-14 women players, an improvement of $3.9 \mathrm{~cm}$ in the players' vertical jumps was seen [42]. The vertical jump measured for under-15 players also improved (by $9.2 \%$ ) after six weeks of regular plyometric training on a gymnasium floor [44]. After a plyometric training protocol that lasted 12 weeks and which was conducted in under- 17 women players, improvements of $16.9 \%$ in counter-movement jumps were found [46]. Also, for the same test in under-22 women players, an improvement of $27.6 \%$ was recorded after 12 weeks of plyometric training [48]. In a study conducted in both men and women players ( 21 years old), it was observed that plyometrics training interventions carried out on grass and on concrete for four weeks promoted improvements of $3.34 \mathrm{~cm}$ and $3.67 \mathrm{~cm}$, respectively, in the counter-jump performance of players [50]. 
Table 2. Studies that investigated the effects of plyometric training programs on vertical jump performance.

\begin{tabular}{|c|c|c|c|c|c|c|}
\hline Study & Sex & $\begin{array}{c}\text { Age (Mean) and } \\
\text { Competitive Level }\end{array}$ & $n$ & Design & Training Protocol & Main Results \\
\hline Martel, Harmer [42] & Women & $\begin{array}{l}\text { Aquatic group: } 14 \text { yo } \\
\text { Control group: } 15 \text { yo }\end{array}$ & 19 & $\begin{array}{c}\text { Randomized } \\
\text { controlled trial; 6-week } \\
\text { period intervention }\end{array}$ & $\begin{array}{l}\text { Aquatic plyometric training (APT): } 2 \times \text { week; } 45 \\
\text { min. Power skips, spike approaches, single- and } \\
\text { double-leg bounding and squat jumps } \\
\text { progressively increased from two times per session } \\
\text { to five times per session. Bouts increased from } 10 \mathrm{~s} \\
\text { to } 30 \text { s of maximal jump during the period. Depth } \\
\text { jumps were performed involving three submerged } \\
\text { boxes also progressively increasing the number of } \\
\text { times session during the period. } \\
\text { Control group (CG): a flexibility supervised } \\
\text { program was conducted twice a week, consisting of } \\
\text { three sets of } 8-10 \text { static stretches for } 30 \mathrm{~s} \text { each. }\end{array}$ & $\begin{array}{l}\text { Meaningful increases in VJ were found } \\
\text { after } 4 \text { weeks in both groups ( } 3 \% \text { in APT } \\
\text { and } 5 \% \text { in CG). After } 6 \text { weeks, the APT } \\
\text { improved } 8 \% \text { in comparison to the } 4 \text {-week } \\
\text { period, and no significant changes were } \\
\text { found in control. } \\
\text { Differences between groups revealed that } \\
\text { players in APT jumped } 1.5 \mathrm{~cm} \text { higher than } \\
\text { CG in baseline and } 3.9 \mathrm{~cm} \text { after the } \\
\text { intervention period. }\end{array}$ \\
\hline Lehnert, Lamrová [46] & Women & 14.8 yo & 11 & $\begin{array}{l}\text { Case reports; } 8 \text {-week } \\
\text { period intervention }\end{array}$ & $\begin{array}{l}2 \times \text { week } \\
\text { The training program was divided into three cycles. } \\
\text { The number of sets varied between } 3 \text { and } 4 \text {, and the } \\
\text { repetitions between } 8 \text { and } 10 \text {. No information } \\
\text { about the resting period was provided. }\end{array}$ & $\begin{array}{l}\text { The standing VJ increased from } 29.50 \mathrm{~cm} \\
\text { at the baseline to } 30.45 \mathrm{~cm} \text { after } 4 \text { weeks of } \\
\text { the program and } 33.54 \mathrm{~cm} \text { at the sixth } \\
\text { week after the completion of the program }\end{array}$ \\
\hline Milić, Nejić [52] & N.R. & 16 yo & 46 & $\begin{array}{l}\text { Case reports; 6-week } \\
\text { period intervention }\end{array}$ & $\begin{array}{l}\text { Plyometric training group: } 2 \text { to } 3 \text { times per week } \\
\text { ( } 15 \text { sessions in total during the experimental } \\
\text { period). Five exercises (hurdle jump, depth jump, } \\
\text { box jump sideways, lunge jumps and vertical } \\
\text { jumps) for explosive leg strength. The number of } \\
\text { sets varied between } 2 \text { and } 4 \text {, and the repetitions } \\
\text { between } 6 \text { and } 12 \text { during the training period. }\end{array}$ & $\begin{array}{l}\text { Meaningful improvements were found in } \\
\text { the plyometric training group: The } \\
\text { two-foot takeoff block jump improved } \\
3.53 \mathrm{~cm} \text {; the right foot takeoff block jump } \\
\text { improved } 3.44 \mathrm{~cm} \text {; the left foot takeoff } \\
\text { block jump improved } 4.05 \mathrm{~cm} \text {; the } \\
\text { two-foot takeoff spike jump improved } \\
5.22 \mathrm{~cm} \text {; the right foot takeoff spike jump } \\
\text { improved } 4.34 \mathrm{~cm} \text {; the left foot takeoff } \\
\text { spike jump improved } 5.39 \mathrm{~cm} \text {; the } \\
\text { standing depth jump improved } 17.95 \mathrm{~cm} \text {; } \\
\text { and the triple standing jump improved } \\
72 \mathrm{~cm} \text {. }\end{array}$ \\
\hline Vassil and Bazanovk [54] & $\begin{array}{l}\text { Men and } \\
\text { women }\end{array}$ & $\begin{array}{l}\text { 14.4 for women and } \\
17.0 \text { yo for men }\end{array}$ & 21 & $\begin{array}{l}\text { Case reports; } 16 \text {-week } \\
\text { period intervention }\end{array}$ & $\begin{array}{l}\text { Twice a week. Squat jumps, lateral box push-offs, } \\
\text { overhead throws, split squats, power drop, depth } \\
\text { jumps, lateral hurdle jumps, plyometric push-ups } \\
\text { and single-leg lateral hops were implemented. } \\
\text { Each session had six exercises repeated twice two } \\
\text { sets), varying the repetitions between } 8 \text { and } 15 .\end{array}$ & $\begin{array}{l}\text { VJ meaningfully improved in girls from } \\
45.3 \text { to } 49.9 \mathrm{~cm} \text {. Despite no significant } \\
\text { changes being found, the jump's height } \\
\text { also increased in men from } 62.1 \text { to } 67.2 \mathrm{~cm}\end{array}$ \\
\hline
\end{tabular}


Table 2. Cont

\begin{tabular}{|c|c|c|c|c|c|c|}
\hline Study & Sex & $\begin{array}{l}\text { Age (Mean) and } \\
\text { Competitive Level }\end{array}$ & $n$ & Design & Training Protocol & Main Results \\
\hline Idrizovic, Gjinovci [56] & Women & 16.6 yo & 47 & $\begin{array}{l}\text { Randomized } \\
\text { controlled trial; } \\
\text { 12-week period } \\
\text { intervention }\end{array}$ & $\begin{array}{l}\text { Three groups: plyometric, skill-based and control. } \\
\text { The plyometric and skill-based groups had two } \\
\text { sessions per week in addition to their regular } \\
\text { training. The plyometric training lasted } 10-15 \\
\text { min/session, and the skill-based training lasted } \\
20-30 \text { min. The plyometric training consisted of } \\
\text { upper and lower limb exercises. The sets of } \\
\text { plyometrics per training varied between } 5 \text { and } 6 \text {, } \\
\text { and the repetitions between } 1 \text { and } 5 \text {. Rest between } \\
\text { sets varieed between } 2 \text { and } 5 \text { min. } \\
\text { The skill-based training consisted of volleyball } \\
\text { drills, small-sided games and real-games drills. }\end{array}$ & $\begin{array}{l}\text { The counter-movement jump improved } \\
16.9 \% \text { in the plyometrics group, } 9 \% \text { in the } \\
\text { skill-based group, and } 8.5 \% \text { in the control } \\
\text { group. Post hoc analysis revealed better } \\
\text { effects of plyometrics in comparison with } \\
\text { the other two training groups for } \\
\text { counter-movement jump performance. }\end{array}$ \\
\hline Myer, Ford [58] & Women & $\begin{array}{l}15.9 \text { yo in plyometric } \\
\text { group and } 15.6 \text { yo in } \\
\text { balance group }\end{array}$ & 18 & $\begin{array}{l}\text { Randomized } \\
\text { controlled trial; 7-week } \\
\text { period intervention }\end{array}$ & $\begin{array}{l}\text { Two experimental groups: plyometric and balance. } \\
\text { Both experimental groups participated in a } \\
\text { common resistance training protocol. Eighteen } \\
\text { experimental training sessions were completed. } \\
\text { Plyometric training included (among other drills) } \\
\text { wall jumps, squat jumps tuck jump, line jumps, } \\
\text { lunge jumps, forward jumps and box drops. The } \\
\text { time dedicated to each exercise varied between } 10 \\
\text { and } 20 \mathrm{~s} \text {, and the repetitions between } 3 \text { and } 10 .\end{array}$ & $\begin{array}{l}\text { Plyometric training significantly } \\
\text { increased knee flexion at the initial contact } \\
\text { and the maximum angle in comparison to } \\
\text { the control group during drop vertical } \\
\text { jump tests. However, balance training } \\
\text { increased maximum knee flexion during } \\
\text { medial drop landing in comparison to } \\
\text { plyometric. Both training protocols were } \\
\text { effective in reducing lower extremity } \\
\text { valgus measures at the hip and at the } \\
\text { ankle and both reduced lower extremity } \\
\text { valgus measures at the knee during a } \\
\text { single-limb dynamic stabilization task. }\end{array}$ \\
\hline Veličković, Bojić [60] & Women & 14 to 16 yo & 30 & $\begin{array}{l}\text { Case reports; } 12 \text {-week } \\
\text { period intervention }\end{array}$ & $\begin{array}{l}\text { Experimental group had two sessions/week. No } \\
\text { information about the training exercises or } \\
\text { planification was provided. }\end{array}$ & $\begin{array}{l}\text { Significant improvements in the } \\
\text { experimental group were observed in the } \\
\text { squat jump }(+5.93 \mathrm{~cm}), \\
\text { counter-movement jump }(+4.98 \mathrm{~cm}) \text {, drop } \\
\text { jump }(4.83 \mathrm{~cm}), \text { and leg squat jump with } \\
\text { preparation }(+3.67 \mathrm{~cm}) \text {. }\end{array}$ \\
\hline Turgut, Colakoglu [43] & Women & $\begin{array}{l}\text { Weighted jump rope } \\
\text { group: } 15.0 \text { yo; } \\
\text { standard jump rope } \\
\text { group } 14.1 \text { yo; } \\
\text { control group: } 14.4 \text { yo }\end{array}$ & 25 & $\begin{array}{l}\text { Randomized } \\
\text { controlled trial; } \\
\text { 12-week period } \\
\text { intervention }\end{array}$ & $\begin{array}{l}\text { Both training groups participated in three } \\
\text { sessions/week. The control group did not } \\
\text { participate in any training protocol. The weighted } \\
\text { jump rope performed rope jumping with weighted } \\
\text { ropes }(600 \mathrm{~g} \text { and } 695 \mathrm{~g}) \text {. The standard jump rope } \\
\text { consisted of a cable rope which weighed between } \\
100 \text { and } 160 \mathrm{~g} \text {. } \\
\text { The training protocol for both groups varied } \\
\text { between } 30 \text { and } 60 \mathrm{~s} \text { per repetition and between } 1 \\
\text { and } 3 \text { sets. }\end{array}$ & $\begin{array}{l}\text { The power during counter-movement } \\
\text { jump tests was significantly improved by } \\
\text { the weighted jump rope protocol in } \\
\text { comparison to the control group (mean } \\
\text { difference of } 11.83 \text { Watts). However, no } \\
\text { meaningful differences were found } \\
\text { between experimental groups. }\end{array}$ \\
\hline
\end{tabular}


Table 2. Cont.

\begin{tabular}{|c|c|c|c|c|c|c|}
\hline Study & Sex & $\begin{array}{l}\text { Age (Mean) and } \\
\text { Competitive Level }\end{array}$ & $n$ & Design & Training Protocol & Main Results \\
\hline Radu, Făgăraş [45] & Women & 16 to 17 yo & 15 & $\begin{array}{l}\text { Case reports; } 10-\text {-week } \\
\text { period intervention }\end{array}$ & $\begin{array}{l}\text { Two plyometric sessions per week. The following } \\
\text { exercises were included in the program: double leg } \\
\text { and single-leg jumps; squat jumps; crossover } \\
\text { jumps; increase and decrease jumps; broad jumps; } \\
\text { box hop jump; scissors jumps; single leg } \\
\text { bounding; and power skipping. }\end{array}$ & $\begin{array}{l}\text { Players meaningfully improved their } \\
\text { overall performance at flight time, contact } \\
\text { time, height, and power during the 15-s } \\
\text { and } 30-\text { s jumping tests. No meaningful } \\
\text { changes were found in stiffness. }\end{array}$ \\
\hline Gjinovci, Idrizovic [48] & Women & 21.9 yo & 41 & $\begin{array}{l}\text { Randomized } \\
\text { controlled trial; } \\
\text { 12-week period } \\
\text { intervention }\end{array}$ & $\begin{array}{l}\text { Two experimental groups: plyometric and } \\
\text { skill-based. Each group had two sessions per week. } \\
\text { Plyometric training included lower-body exercises } \\
\text { (leg hops, vertical jumps, tuck jumps, } \\
\text { lateral/diagonal jumps, broad jumps, obstacle } \\
\text { jumps, box jumps, and drop jumps) and upper } \\
\text { body exercises (throwing exercises). The total of } \\
\text { sets/week varied between } 12 \text { and } 24 \text { depending on } \\
\text { the body part, and the repetitions between } 40 \text { and } \\
\text { 58/week. Skill-based training consisted of } \\
\text { volleyball drills, small-sided games, and } \\
\text { game drills. }\end{array}$ & $\begin{array}{l}\text { Both groups showed meaningful } \\
\text { improvements in counter-movement } \\
\text { jump performance. The plyometric group } \\
\text { had an improvement of } 27.6 \% \text {, and the } \\
\text { skill-based group had an improvement of } \\
18 \% \text {. Plyometric training was largely } \\
\text { better than skill-based training } \\
\text { considering the effects on } \\
\text { counter-movement jump performance. }\end{array}$ \\
\hline Hewett, Stroupe [44] & Women & 15 yo & 20 & $\begin{array}{l}\text { Case reports; 6-week } \\
\text { period intervention }\end{array}$ & $\begin{array}{l}\text { Experimental group had three sessions per week. } \\
\text { The program followed three phases: Technique } \\
\text { phase ( } 2 \text { first weeks), fundamentals phase (using a } \\
\text { proper technique to build strength and power) and } \\
\text { performance phase (focusing on achieving } \\
\text { maximal jumping). }\end{array}$ & $\begin{array}{l}\text { The plyometric group meaningfully } \\
\text { improved vertical jump performance by } \\
9.2 \% \text {. Decreases in peak landing forces } \\
\text { were observed. }\end{array}$ \\
\hline Hrženjak, Trajković [47] & Women & $\begin{array}{l}\text { Youth and junior } \\
\text { plyometric group: } \\
16.18 \text { yo. } \\
\text { Control group: } 16.3 \text { yo. }\end{array}$ & $\begin{array}{c}N=60 \\
\text { Plyometric } \\
\text { group } \\
(n=31) ; \\
\text { control } \\
\text { group } \\
(n=29)\end{array}$ & $\begin{array}{l}\text { Randomized } \\
\text { controlled trial; } 6 \\
\text {-week period } \\
\text { intervention }\end{array}$ & $\begin{array}{l}6 \text { weeks; five training sessions per week ( } 90 \text { to } 120 \\
\text { min). The number of training sessions was } 15 . \\
\text { The set model for development of explosive leg } \\
\text { power consisted of five exercises, and exercises } \\
\text { were done in the first part of the training session, } \\
\text { after a } 30 \text {-min warm-up. }\end{array}$ & $\begin{array}{l}\text { Both the plyometric and the control group } \\
\text { showed significant improvements ( } p< \\
0.05) \text { in joint kinematics from pre- to } \\
\text { post-training on most of the measures for } \\
\text { linear velocity, except for the linear } \\
\text { velocity in the hips during the eccentric } \\
\text { phase }(p=0.669 \text { for the plyometric group, } \\
p=0.595 \text { for the control group), where } \\
\text { none of the group showed significant } \\
\text { improvement. }\end{array}$ \\
\hline
\end{tabular}


Table 2. Cont.

\begin{tabular}{|c|c|c|c|c|c|c|}
\hline Study & Sex & $\begin{array}{l}\text { Age (Mean) and } \\
\text { Competitive Level }\end{array}$ & $n$ & Design & Training Protocol & Main Results \\
\hline Trajkovic, Kristicevic [49] & Women & 17 yo & 60 & $\begin{array}{l}\text { Case reports; 6-week } \\
\text { period intervention }\end{array}$ & $\begin{array}{l}\text { Twelve sessions were completed during the } \\
\text { experimental period. The plyometric training } \\
\text { program consisted of the following exercises: } \\
\text { hurdle jumps, depth jumps, lateral jumps over box } \\
\text { jumps, lunge jumps and vertical jumps. The } \\
\text { number of sets per session varied between } 2 \text { and } 4 \text {, } \\
\text { and the repetitions between } 6 \text { and } 12 \text {. }\end{array}$ & $\begin{array}{l}\text { Meaningful within-plyometric group } \\
\text { improvements were observed in right } \\
(+2.36 \mathrm{~cm}) \text { and left }(+2.48 \mathrm{~cm}) \text { foot block } \\
\text { jump, crossover jump }(+2.64 \mathrm{~cm}) \text { and } \\
\text { sidestep block jump }(+3.36 \mathrm{~cm}) \\
\text { performance. Changes were also } \\
\text { significantly different from the } \\
\text { control group. }\end{array}$ \\
\hline Çankaya, Arabacı [51] & Women & 16 yo & 10 & $\begin{array}{l}\text { Case reports; } 4 \text {-week } \\
\text { period intervention }\end{array}$ & $\begin{array}{l}\text { Six experimental sessions per week. Three sets of } \\
30 \text { jumps were added to the regular } \\
\text { training session. }\end{array}$ & $\begin{array}{l}\text { Meaningful increases in jumping height } \\
\text { were found between the baseline }(33.8 \mathrm{~cm}) \\
\text { and weeks } 3(36.0 \mathrm{~cm}) \text { and } 4(36.4 \mathrm{~cm}) .\end{array}$ \\
\hline Ramlan, Pitil [50] & $\begin{array}{l}\text { Men and } \\
\text { women }\end{array}$ & 21 yo & 12 & $\begin{array}{l}\text { Randomized } \\
\text { controlled trial; 4-week } \\
\text { period intervention }\end{array}$ & $\begin{array}{l}\text { Two experimental groups: Plyometrics on grass } \\
\text { and plyometrics on concrete surface. Both groups } \\
\text { trained twice a week with the same number of sets, } \\
\text { repetitions and resting time. The programs } \\
\text { included the following exercises: drop from a } \\
\text { platform, double leg jump over a hurdle, double } \\
\text { leg drop jump and double leg drop jump over a } \\
\text { hurdle. The number of repetitions varied between } \\
3 \text { and } 6 \text { sets of } 12 \text { and } 7 \text { repetitions, depending on } \\
\text { the exercise. }\end{array}$ & $\begin{array}{l}\text { Both groups improved their squat and } \\
\text { counter-movement jumps after the } \\
\text { training period. The plyometrics group } \\
\text { on grass improved from } 38.83 \text { to } 42.00 \mathrm{~cm} \\
\text { in the squat jump, and the plyometrics } \\
\text { group on concrete from } 39.33 \text { to } 41.50 \mathrm{~cm} \text {. } \\
\text { Moreover, the plyometrics group on grass } \\
\text { improved their counter-movement jumps } \\
\text { from } 36.83 \text { to } 40.17 \mathrm{~cm} \text {, and the } \\
\text { plyometrics group on concree from } 35.33 \\
\text { to } 39.00 \mathrm{~cm} \text {. No significant differences } \\
\text { between groups were found. }\end{array}$ \\
\hline
\end{tabular}

Yo: years old; VJ: vertical jump; N.R.: not reported. 
Table 3. Studies that investigated the effects of plyometric training programs on strength performance.

\begin{tabular}{|c|c|c|c|c|c|c|}
\hline Study & Sex & $\begin{array}{l}\text { Age (Mean) and } \\
\text { Competitive Level }\end{array}$ & $n$ & Design & Training Protocol & Main Results \\
\hline Martel, Harmer [42] & Women & $\begin{array}{l}\text { Aquatic group: } 14 \text { yo } \\
\text { control group: } 15 \text { yo }\end{array}$ & 19 & $\begin{array}{l}\text { Randomized } \\
\text { controlled trial; 6-week } \\
\text { period intervention }\end{array}$ & $\begin{array}{l}\text { Aquatic plyometric training (APT): } 2 \times \text { week; } \\
45 \text { min. Power skips, spike approaches, } \\
\text { single- and double-leg bounding, and squat } \\
\text { jumps progressively increased from two } \\
\text { times per session to five times per session. } \\
\text { Bouts increased from } 10 \mathrm{~s} \text { to } 030 \text { so maximal } \\
\text { jump during the period. Depth jumps were } \\
\text { performed involving three submerged boxes } \\
\text { also progressively increasing the number of } \\
\text { times session during the period. } \\
\text { Control group (CG): A flexibility supervised } \\
\text { program was conducted twice a week, } \\
\text { consisting of three sets of } 8-10 \text { static stretches } \\
\text { for } 30 \text { s each. }\end{array}$ & $\begin{array}{l}\text { There were no significant differences in } \\
\text { concentric peak torque in either the dominant } \\
\text { or nondominant leg between the APT and } \\
\text { traditional volleyball training groups } \\
\text { at baseline. } \\
\text { Similar significant improvements in } \\
\text { concentric peak torque were observed in the } \\
\text { dominant leg of both groups when } \\
\text { comparing baseline values with those } \\
\text { obtained after } 6 \text { weeks. } \\
\text { The improvements in both groups were } \\
\text { similar for knee extension and flexion at both } \\
60^{\circ} \text { and } 180^{\circ} \text {. }\end{array}$ \\
\hline Hewett, Stroupe [44] & Women & 15 yo & 20 & $\begin{array}{l}\text { Case reports; 6-week } \\
\text { period intervention }\end{array}$ & $\begin{array}{l}\text { Experimental group had three sessions per } \\
\text { week. The program followed three phases: } \\
\text { technique phase (two first weeks), } \\
\text { fundamentals phase (using a proper } \\
\text { technique to build strength and power), and } \\
\text { performance phase (focusing on achieving } \\
\text { maximal jumping). }\end{array}$ & $\begin{array}{l}\text { Isokinetic peak torque increased } 26 \% \text { in the } \\
\text { non-dominant leg and } 13 \% \text { in the dominant leg. } \\
\text { The hamstring-to-quadriceps muscle peak } \\
\text { torque ratio increased } 13 \% \text { on the dominant } \\
\text { side and } 26 \% \text { on the non-dominant side. }\end{array}$ \\
\hline Mroczek, Superlak [53] & Men & $\begin{array}{c}21 \text { yo } \\
2 \text { nd league }\end{array}$ & 16 & $\begin{array}{l}\text { Case reports; 6-week } \\
\text { period intervention }\end{array}$ & $\begin{array}{l}\text { Measuring muscle stiffness: } \\
\text { Three measurements performed once per week } \\
\text { over } 6 \text { consecutive weeks of plyometric } \\
\text { training (before the warm-up): In week } 0 \text {, } \\
\text { week } 4 \text { (the effects of the training completed in } \\
\text { week } 3 \text { ) and week } 6 \text { (the effects of the training } \\
\text { carried out in week } 5 \text { ). Individual assessments } \\
\text { lasted up to } 4 \mathrm{~min}, \text { and the participants } \\
\text { underwent them in a random order. }\end{array}$ & $\begin{array}{l}\text { The analysis of stiffness levels in the posterior } \\
\text { parts of the thigh revealed significant } \\
\text { differences between the points in the left and } \\
\text { right limbs only in the posterior muscles. } \\
\text { Significant differences were observed for the } \\
\text { semitendinosus immediately before the } \\
\text { experiment started, whereas the differences } \\
\text { were insignificant in the fourth and sixth } \\
\text { training sessions. }\end{array}$ \\
\hline Bashir, SulehHayyat [55] & Men & N. R. & $\begin{array}{l}\quad 45 \\
\text { G1-plyometric } \\
\text { training (15); } \\
\text { G2-weight and } \\
\text { plyometric (15); } \\
\text { G3-control } \\
\text { group (15) }\end{array}$ & $\begin{array}{l}\text { Randomized } \\
\text { controlled trial; } \\
\text { 12-week period } \\
\text { intervention }\end{array}$ & $\begin{array}{l}\text { Group I and II underwent respective training } \\
\text { programs for } 3 \text { days per week for } 12 \text { weeks } \\
\text { under the instruction and supervision of the } \\
\text { investigator. } \\
\text { Group-I performed plyometric training with } \\
\text { a training intensity of } 65 \%-80 \% \text { of their } 1 R M \\
\text { and the subjects of experimental Group-II } \\
\text { performed a combination of weight and } \\
\text { plyometric training with a training intensity } \\
\text { of } 65 \%-80 \% \text { of their } 1 \text { RM. }\end{array}$ & $\begin{array}{l}\text { Differences in muscular strength between } \\
\text { plyometric training and control groups were } \\
\text { significant at the } 0.05 \text { level of confidence. } \\
\text { No significant difference between plyometric } \\
\text { and combination of weight and plyometric } \\
\text { training groups (0.37) in muscular strength } \\
\text { after the training program. } \\
\text { Differences in muscular endurance between } \\
\text { plyometric training and control groups and a } \\
\text { combination of weight and plyometric } \\
\text { training and control group were significant. } \\
\text { No significant difference between plyometric } \\
\text { and combination of weight and plyometric } \\
\text { training groups on muscular endurance after } \\
\text { the training program. }\end{array}$ \\
\hline
\end{tabular}


Table 4. Studies that investigated the effects of plyometric training programs on horizontal jump performance.

\begin{tabular}{|c|c|c|c|c|c|c|}
\hline Study & Sex & $\begin{array}{c}\text { Age (Mean) and } \\
\text { Competitive Level }\end{array}$ & $n$ & Design & Training Protocol & Main Results \\
\hline Milić, Nejić [52] & N.R. & 16 yo & 46 & $\begin{array}{l}\text { Case reports; 6-week } \\
\text { period intervention }\end{array}$ & $\begin{array}{l}\text { Plyometric training group: } 2 \text { to } 3 \text { times per } \\
\text { week (15 sessions in total during the } \\
\text { experimental period). Five exercises (hurdle } \\
\text { jump, depth jump, box jump sideways, lunge } \\
\text { jumps and vertical jumps) for explosive leg } \\
\text { strength. The number of sets varied between } \\
2 \text { and 4, and the repetitions between } 6 \text { and } 12 \\
\text { during the training period. }\end{array}$ & $\begin{array}{l}\text { A considerable increase in jumping skill was found } \\
\text { among the members of the experimental group. } \\
\text { Regarding the standing long jump, results reveal } \\
\text { significant values ( } \mathrm{F}=5.55 ; p=0.024 \text { ). }\end{array}$ \\
\hline Vassil and Bazanovk [54] & $\begin{array}{l}\text { Men and } \\
\text { women }\end{array}$ & $\begin{array}{l}14.4 \text { for women and } 17.0 \text { yo } \\
\text { for men }\end{array}$ & 21 & $\begin{array}{c}\text { Case reports; 16-week } \\
\text { period intervention }\end{array}$ & $\begin{array}{l}\text { Twice a week. Squat jumps, lateral box } \\
\text { push-offs, overhead throws, split squats, } \\
\text { power drop, depth jumps, lateral hurdle } \\
\text { jumps, plyometric push-ups and single-leg } \\
\text { lateral hops were implemented. Each session } \\
\text { had six exercises repeated twice (two sets), } \\
\text { varying the repetitions between } 8 \text { and } 15 .\end{array}$ & $\begin{array}{l}\text { The women averaged changes from } 194.8 \pm 13.2 \mathrm{~cm} \\
\text { to } 203.3 \pm 13.2 \mathrm{~cm}(p>0.05) \text {. and men's results } \\
\text { averaged improvements of } 240.9 \pm 16.7 \mathrm{~cm} \text { to } 248 \pm \\
15.5 \mathrm{~cm}(p>0.05) \text {. } \\
\text { The women's average depth leap long jump girl's } \\
\text { group average increased from } 185.3 \pm 14.7 \mathrm{~cm} \text { to } \\
193.8 \pm 13.6 \mathrm{~cm}(p>0.05) \text {, and the men's results } \\
\text { averaged an increase from } 238.3 \pm 17 \mathrm{~cm} \text { to } 246.4 \pm \\
17.7 \mathrm{~cm}(p>0.05) .\end{array}$ \\
\hline Gjinovci, Idrizovic [48] & Women & 21.9 yo & 41 & $\begin{array}{l}\text { Randomized } \\
\text { controlled trial; } \\
\text { 12-week period } \\
\text { intervention }\end{array}$ & $\begin{array}{l}\text { Two experimental groups: Plyometric and } \\
\text { skill-based. Each group had two sessions per } \\
\text { week. Plyometric training included } \\
\text { lower-body exercises (leg hops, vertical jumps, } \\
\text { tuck jumps, lateral/diagonal jumps, broad } \\
\text { jumps, obstacle jumps, box jumps and drop } \\
\text { jumps) and upper body exercises (throwing } \\
\text { exercises). The total of sets//week varied } \\
\text { between } 12 \text { and } 24 \text { depending on the body part, } \\
\text { and the repetitions between } 40 \text { and } 58 / \text { week. } \\
\text { Skilll-based training consisted of volleyball } \\
\text { drills, small-sided games and game drills. }\end{array}$ & $\begin{array}{l}\text { The plyometric group significantly ( } p<0.05 \text { ) } \\
\text { reduced their body-mass (trivial ES differences; } 1 \% \\
\text { pre- to post-measurement changes) and improved } \\
\text { their performance in the horizontal jump test } \\
\text { (moderate ES differences; } 7.6 \% \text { changes). Players } \\
\text { involved in skill-based-conditioning improved their } \\
\text { capacities for horizontal jumping (small ES } \\
\text { differences; } 3.1 \% \text { changes). }\end{array}$ \\
\hline Çımenlı, Koç [57] & Male & 18 to 24 yo & $\begin{array}{c}N=36 \\
12 \text { control group, } \\
12 \text { wooden surface } \\
\text { group, } \\
12 \text { synthetic } \\
\text { surface group }\end{array}$ & $\begin{array}{l}\text { Randomized } \\
\text { controlled trial; } \\
\text { 12-week period } \\
\text { intervention }\end{array}$ & $\begin{array}{l}\text { Plyometric training was practiced } 3 \text { days per } \\
\text { week for } 8 \text { weeks. Each training session } \\
\text { lasted about } 50-60 \text { min. Subjects performed } 1 \\
\text { or } 2 \text { sets of } 10 \text { repetitions according to the } \\
\text { training number }(1 \text { to } 24) \text {. } \\
\text { The tests applied to verify the horizontal } \\
\text { jump were the right and left foot jump; } \\
\text { double foot jump; right and left foot by } \\
\text { taking a step. }\end{array}$ & $\begin{array}{l}\text { In intra-group comparisons of the control group's } \\
\text { right foot, left foot, double foot and left foot by } \\
\text { taking one step jump and the experimental group's } \\
\text { right foot, left foot, double foot, right foot by taking } \\
\text { one step jump and left foot by taking one step jump } \\
\text { values displayed a significant difference ( } p<0.05) \text {. } \\
\text { However, the experimental group's right foot taking } \\
\text { one step jump values did not differ significantly } \\
\text { from the control group's. } \\
\text { During the post-test comparisons between groups, a } \\
\text { significant difference was found between the right } \\
\text { foot, taking a step with the right foot, and taking a } \\
\text { step with the left foot values }(p<0.05) \text {. On the other } \\
\text { hand, the right foot and double foot jump values did } \\
\text { not differ significantly. }\end{array}$ \\
\hline
\end{tabular}




\subsubsection{Effects of Plyometric Training on Strength Performance}

Four of the 19 articles included in this systematic review presented inferences about the effects of plyometric training on the strength performance of athletes (Table 3). The strength tests included those for peak torque of lower limb (i.e., concentric and eccentric peak torque), isokinetic peak torque of hamstrings and weight and plyometric training. The literature included two studies with male volleyball players and two with female volleyball players, ranging from 14 to 21 years of age, with three of these studies being conducted in youth. No studies compared men's and women's results. All four studies are cohort-studies which included either a six-week intervention period $[42,44,52]$ or a 12-week intervention period [54].

Beyond the influence of plyometric training on the stiffness of the lower limbs [52], research has highlighted the effect of aquatic plyometric training on strength performance, which improves the concentric peak torque in the dominant leg [42]. Furthermore, weight training sessions that include exercises for the upper body, lower body, and trunk increase isokinetic peak torque by $13 \%$ on the dominant side and by $26 \%$ on the non-dominant side [44].

\subsubsection{Effects of Plyometric Training on Horizontal Jump}

Four studies included in this systematic review presented inferences about the effects of plyometric training on horizontal jump performance (Table 4). The horizontal jump tests included two exercises: The standing long jump and the depth leap long jump. One study included both male and female participants [56], one included only males [58] and another included only females [48]. The study conducted by Milic et al. [52] did not report the genre of the participants. Two studies are cohort studies involving competitive-level youth players (one of which employed a six-week intervention period and one of which utilized a 16-week intervention period), and the other two studies were randomized controlled studies involving 12-week intervention periods with athletes between the ages of 18 and 24 years.

Studies conducted by Milić et al. [52] and Çımenlı et al. [57] revealed a significant increase in horizontal jump performance after the plyometric training intervention. However, another study did not show significant differences in this regard [56], and the study carried out by Gjinovci et al. [48] presented only a small effect of plyometric training on horizontal jump performance.

\subsubsection{Effects of Plyometric Training on Flexibility}

Only two articles included in this systematic review presented inferences about the effects of plyometric training on flexibility (Table 5). The flexibility measure was based on the sit and reach test, which is used to examine the flexibility of the hamstring and lower back. The participants of these two studies were female youth volleyball players. One study was a cohort study with a 12-week intervention period [43], and the other was a randomized controlled trial which also had an intervention period of 12 weeks [45]. The results of these studies reveal that plyometric training can improve flexibility by $9 \%$ [43] to $14 \%$ [45].

\subsubsection{Effects of Plyometric Training on Agility/Speed}

This systematic review found three studies which observed the effects of plyometric training on the agility/speed of volleyball players $[43,46,47]$. The results can be found in Table 6 . The tests used in these studies included a $20 \mathrm{~m}$ sprint [43], a zigzag double-leg jump over the line combined with a shuttle run $(6 \mathrm{~m} \times 6 \mathrm{~m})$ [46], and a shuttle run for which the distance was not reported [47]. 
Table 5. Studies that investigated the effects of plyometric training programs on flexibility.

\begin{tabular}{|c|c|c|c|c|c|c|}
\hline Study & Sex & $\begin{array}{l}\text { Age (Mean) and } \\
\text { Competitive Level }\end{array}$ & $n$ & Design & Training Protocol & Main Results \\
\hline Idrizovic, Gjinovci [56] & Women & 16.6 yo & 47 & $\begin{array}{l}\text { Randomized } \\
\text { controlled trial; } \\
\text { 12-week period } \\
\text { intervention }\end{array}$ & $\begin{array}{l}\text { Three groups: Plyometric, skill-based and control. } \\
\text { The plyometric and skill-based groups had two } \\
\text { sessions per week in addition to their regular } \\
\text { training. The plyometric training lasted } 10-15 \\
\text { min/session, and the skill-based training lasted } \\
20-30 \text { min. The plyometric training consisted of } \\
\text { upper and lower limb exercises. The sets of } \\
\text { plyometrics per training varied between } 5 \text { and } 6 \text {, } \\
\text { and the repetitions between } 1 \text { and } 5 \text {. Rest between } \\
\text { sets varied between } 2 \text { and } 5 \text { min. } \\
\text { The skill-based training consisted of volleyball } \\
\text { drills, small-sided games and real-games drills. }\end{array}$ & $\begin{array}{l}\text { The main significant analysis of variance effects } \\
\text { for time was observed for SIT-AND- REACH } \\
\text { (F = 75.93, } p<0.01 \text {; small ES). } \\
\text { Significant group } \times \text { time interactions were } \\
\text { observed SIT-AND-REACH ( } \mathrm{F}=11.70, p<0.01 \text {; } \\
\text { large ES). } \\
\text { Post hoc differences were significant for } \\
\text { SIT-AND-REACH, with better training effects of } \\
\text { plyometric and skill-based conditioning when } \\
\text { compared with the control program (9.1\%; almost } \\
\text { certainly positive). }\end{array}$ \\
\hline Turgut, Colakoglu [43] & Women & $\begin{array}{l}\text { Weighted jump rope group: } \\
15.0 \text { yo; standard jump rope } \\
\text { group } 14.1 \text { yo; Control } \\
\text { group: } 14.4 \text { yo }\end{array}$ & 25 & $\begin{array}{l}\text { Randomized } \\
\text { controlled trial; } 12 \\
\text { week period } \\
\text { intervention }\end{array}$ & $\begin{array}{l}\text { Group I-Weighted jump rope training group: } \\
\text { Performed rope jumping with weighted ropes and } \\
\text { followed the program for twelve weeks, three } \\
\text { times weekly. } \\
\text { Group II-Standard jump rope training group: } \\
\text { Followed the program for twelve weeks, three } \\
\text { times weekly. } \\
\text { Control Group: Followed a routine volleyball } \\
\text { training program. } \\
\text { Anaerobic power was measured by a vertical jump } \\
\text { test (Lewis formula: Power }=\sqrt{ } 4.9 \times \text { body mass } \\
(\mathrm{kg}) \times \sqrt{ } \text { vertical jump score }(\mathrm{m}) \times 9.81) ; 30 \mathrm{~m} \text { sprint } \\
\text { test; hexagonal obstacle test and zigzag test; sit and } \\
\text { reach test. }\end{array}$ & $\begin{array}{l}\text { There was a statistically significant main effect of } \\
\text { time }(\mathrm{F}=59.05 ; p<0.001) \text { for sit and reach test } \\
\text { outcomes }(24.9 \mathrm{~cm} \text { for recordings at baseline } \\
\text { versus } 28.5 \mathrm{~cm} \text { for recordings after } 12 \text { weeks of } \\
\text { training), indicating that all groups gained } \\
\text { flexibility according to sit and reach test results. }\end{array}$ \\
\hline
\end{tabular}


Table 6. Studies that investigated the effects of plyometric training programs on agility/speed.

\begin{tabular}{|c|c|c|c|c|c|c|}
\hline Study & Sex & $\begin{array}{l}\text { Age (Mean) and } \\
\text { Competitive Level }\end{array}$ & $n$ & Design & Training Protocol & Main Results \\
\hline Lehnert, Lamrová [46] & Women & 14.8 yo & 11 & $\begin{array}{l}\text { Case Report; 8-week } \\
\text { period intervention }\end{array}$ & $\begin{array}{l}\text { Tests before and after plyometric sessions: } \\
\text { Standing vertical jump (height of the jump in } \\
\mathrm{cm} \text { ), vertical jump with approach (height of the } \\
\text { jump in } \mathrm{cm} \text { ), shuttle run for } 6 \times 6 \mathrm{~m} \\
2 \times \text { week } \\
\text { The training program was divided into three } \\
\text { cycles. The number of sets varied between } 3 \text { and } \\
4 \text {, and the repetitions between } 8 \text { and } 10 \text {. No } \\
\text { information about the resting period } \\
\text { was provided. }\end{array}$ & $\begin{array}{l}\text { Positive trend with differences (with no } \\
\text { significant values }-Z=3.01 \text { ) between } \\
\text { speed values during the training } \\
\text { program. }\end{array}$ \\
\hline Idrizovic, Gjinovci [56] & Women & 16.6 yo & 47 & $\begin{array}{l}\text { Randomized } \\
\text { controlled trial; } \\
\text { 12-week period } \\
\text { intervention }\end{array}$ & $\begin{array}{l}\text { Three groups: Plyometric, skill-based and } \\
\text { control. The plyometric and skill-based groups } \\
\text { had two sessions per week in addition to their } \\
\text { regular training. The plyometric training lasted } \\
10-15 \text { min/session, and the skill-based training } \\
\text { lasted } 20-30 \text { min. The plyometric training } \\
\text { consisted of upper and lower limb exercises. The } \\
\text { sets of plyometrics per training varied between } 5 \\
\text { and } 6 \text {, and the repetitions between } 1 \text { and } 5 \text {. Rest } \\
\text { between sets varied between } 2 \text { and } 5 \text { min. } \\
\text { The skill-based training consisted of volleyball } \\
\text { drills, small-sided games and real-games drills. }\end{array}$ & $\begin{array}{l}\text { The main effects for groups were } \\
\text { significant for SPRINT20M ( } \mathrm{F}=3.77, \\
p<0.05 ; \text {; large ES). } \\
\text { Post hoc analyses indicated greater } \\
\text { effects of plyometric training in } \\
\text { comparison with the other two training } \\
\text { programs for SPRINT20M. }\end{array}$ \\
\hline Sheikh and Hassan [59] & Male & Between 18 and 22 yo & $\begin{array}{l}\quad N=45 \\
\text { Experimental Group: I } \\
\text { and II (15 + 15) } \\
\text { Control Group: } 15\end{array}$ & $\begin{array}{l}\text { Randomized } \\
\text { controlled trial; } \\
\text { 12-week period } \\
\text { intervention }\end{array}$ & $\begin{array}{l}\text { Group I and II-12 week, } 3 \times \text { week ( } 45 \mathrm{~min} \\
\text { per session) } \\
\text { Exercises: } \\
50 \mathrm{~m} \text { sprint; shuttle run; side to side leg } \\
\text { bounding, jump to box; tuck jump; depth jump. } \\
\text { Group I: Plyometric training with weighted vest } \\
\text { ( } 2 \text { kg) Group II: Plyometric training without } \\
\text { weighted vest } \\
\text { Side to side leg bounding, jump to box, tuck } \\
\text { jump, depth jump. These exercises were } \\
\text { performed for } 45 \text { min each day. }\end{array}$ & $\begin{array}{l}\text { There is a significant difference between } \\
\text { the plyometric training with a weighted } \\
\text { vest group and the control group as well } \\
\text { as between the plyometric training } \\
\text { without a weighted vest group and the } \\
\text { control group in terms of agility. Twelve } \\
\text { weeks of plyometric training with a } \\
\text { weighted vest resulted in greater } \\
\text { improvements than twelve weeks of } \\
\text { plyometric training without a weighted. }\end{array}$ \\
\hline
\end{tabular}


Two of the three studies included female youth volleyball players; the other study included 18- to 22-year-old male volleyball players.

The results of one study revealed that an eight-week intervention period significantly improved participants' speed [46]. Corroborating these results, a post hoc analysis indicated improvements in speed values in a $20 \mathrm{~m}$ sprint [43]. Finally, after a 12-week plyometric training program, it was shown that participants who completed the training program while wearing a weighted vest showed greater improvements in agility than those who did not wear a weighted vest [47].

\section{Discussion}

\subsection{Effect of Plyometric Training on Vertical Jump Performance}

The purpose of plyometric training is to improve the power of subsequent movements using both the natural elastic components of the muscles and tendons as well as stretch reflex [49]. Considering that jump performance ability is highly influenced by the individual's ability to take advantage of the elastic and neural benefits of the SSC, well-developed strength and the rate of excursion of the activated musculature during the contraction, it is expected that plyometric training may benefit athletes' jumping performance [51]. In fact, the literature is consistent in suggesting that plyometric training contributes to the optimization of landing mechanisms [53], improvements in eccentric muscle control and an increase in knee flexion and hamstring activity [55].

Improvements in jumping performance (independent of the type of jump analyzed) were observed in all the studies presented in Table 2. Moreover, such benefits were observed in both males and females and independently of age. In theory, it is expected that meaningful improvements on the jumping performance will be observed after the implementation of a plyometric training intervention, with larger increases in counter-movement or drop jumps than in squat jumps.

Such a hypothesis is based on the fact that counter-movement and drop jumps are more dependent on SSC than squat jumps. When performing a squat jump, a pause occurs during the amortization phase, leading to the dissipation of elastic potential energy and a decrease in the potentization effect based on SSC [57]. In a study that compared plyometric training (i.e., young adults; men and women) carried out on grass with plyometric training carried out on concrete, improvements of 3.17 and $2.17 \mathrm{~cm}$, respectively, in squat jump performance and of 3.34 and $3.67 \mathrm{~cm}$, respectively, in counter-movement were observed [50]. However, in a study which involved a 12-week training period on young adult men and which tested more than one type of jump, it was observed that improvements were slightly greater for the squat jump $(+5.93 \mathrm{~cm})$ than counter-movement $(+4.98 \mathrm{~cm})$ and drop jumps $(+4.83 \mathrm{~cm})$ [59].

These two studies are not enough to generalize the idea that plyometric training is more beneficial for counter-movement and drop jumps in volleyball players. However, it is important to note that such a hypothesis has been supported in a systematic review of women athletes from different sports [51]. For that reason, future studies conducted on volleyball players should include more than one type of vertical jump test to analyze the different effects of plyometric training on players' performance.

Throughout the articles reviewed presently, a clear tendency to conduct studies in young (under-18) women players was observed. No study included in the review analyzed men exclusively, and only a couple of articles tested the effects of plyometric training on adults. This is a limitation to understanding the general effects of plyometric training on volleyball players. In fact, the effectiveness of plyometric training may depend on different factors such as age, maturation, sex or training level [51]. Among these variables, maturation seems especially likely to be a determinant factor in explaining the effectiveness and the responsiveness of athletes to plyometric training [61]. However, in in the articles reviewed, no study analyzed the maturation status of players. This is an important gap in the research that should be considered and corrected in further studies conducted in youth players.

The effectiveness of plyometric training may also depend on the training design and the length of the intervention period [51]. Regarding the training design, it is common for researchers to describe certain variables, such as the type of exercises used, the training duration, recovery status and the 
frequency, volume and intensity of the training. However, there is a lack of information about other potentially important concurrent factors that may explain some of the variations in the results. In fact, the jumping technique and the influence of movement amplitude or ground-contact time were not described in any of the reviewed studies' protocols [57].

Another common omission of information observed throughout the included studies was the type of surface that the tests were conducted on; this factor may affect the outcomes of a training program. However, in a study that tested the effects of plyometric training completed on grass or on concrete, it was observed that both training types improved the jumping performance of volleyball athletes, with no significant differences found between the two groups [50]. Also, when testing plyometric interventions in a non-solid aquatic environment, meaningful improvements in vertical jump performance were observed [42].

Another important factor that may determine the effectiveness or the amplitude of the benefits of plyometric interventions is the duration of the training period. It was observed that the interventions implemented in the reviewed studies ranged from four to 16 weeks $[56,62]$, with periods of $6[42,44,60,63]$ and 12 weeks $[43,45,48,59]$ being the most common. In the reviewed studies, improvements of $8 \%$ [42] and 9.2\% [44] in the vertical jump were reported in two of the studies that used six-week plyometric training protocols. Meanwhile, improvements of 16.9\% [43] and 27.6\% [48] were observed in counter-movement jumps in two of the studies which included 12-week training period protocols. It is possible that plyometric training programs of longer than 10 weeks are more helpful in obtaining meaningful improvements [51,64].

One of the main study limitations is associated with the non-report of individualized training intensity for each participant and possible confounding effects on the final outcomes. Moreover, it is necessary for a deep understanding of the effects of plyometric training on the reactive strength index.

\subsection{Effects of Plyometric Training on Strength}

Volleyball is a complex sport for which several athletic demands need to be developed [65]. One of these demands is strength because of its relevance to the technical skills used in volleyball, such as jumping, hitting and blocking. Thus, muscular strength is one of the most important factors that give players an advantage during elite-level competitions [66].

The effect of plyometric training on strength was analyzed in four studies [52]. The strength tests included examinations of peak torque of lower limb (concentric and eccentric peak torque) [42,44], isokinetic peak torque of hamstrings [52] and a combination of weight and plyometric training [54]. The benefits of plyometric training in the muscle strength was observed in both sexes and in all ages analyzed (i.e., 14-21 years old).

Beyond the influence of plyometric training on the stiffness of lower limbs [52], one of the analyzed studies showed that plyometric training improved strength performance in the dominant leg of participants of under-15 women [42]. Also, strength performance was improved when weight and plyometric training were combined and included exercises for the upper body, lower body and trunk in under-17 men and women [54]. Furthermore, plyometric training was found to improve strength on both the dominant side $(26 \%)$ and non-dominant side $(13 \%)$ in terms of isokinetic peak torque in under-15 women [44]. The results revealed that plyometric training increases strength regardless of the number of weeks spent training or the assessment procedures used. However, contrary to the results found in the review, in a study that assessed the level of specific lower limb power and reactive force in young female volleyball players, the stiffness test revealed no significant differences for any variables after 10 weeks of plyometric training [67].

Some possible explanations to justify the gains of strength are that plyometric training requires an appropriate technical ability as well as sufficient levels of muscle strength and joint coordination, thus increasing the inter- and intra-muscle capacity to contract and produce force [68,69]. However, it seems that a combined training program may also contribute to benefits in muscle strength. 
When comparing the impact of short-term training with resistance plus plyometric training $(\mathrm{RT}+\mathrm{P})$ or electromyostimulation plus plyometric training $(\mathrm{EMS}+\mathrm{P})$ on explosive strength production in elite volleyball players, the results indicate that the first is effective in promoting jump performance, while the latter helps with increasing the jump performance, speed and agility of elite volleyball players [70]. Besides that, one study showed that an eight-week-long training program which combined jumping and ball throwing training resulted in significantly improved muscular performance in young female volleyball players [45].

One possible explanation for the results reported in three of the four studies in this review which analyzed six-weeks plyometric training programs in youth athletes is that, as mentioned in the research of Ziv and Lidor [16], at least eight weeks of training are needed, specifically for motor capacity, for the development of strength, especially when the participants are young.

Beyond the few studies reported, there is a lack of evidence about the plyometric effect on essential strength parameters such as force production rate in both concentric and eccentric phases. The improvement of future studies should consider such an analysis.

\subsection{Effects of Plyometric Training on Horizontal Jump}

The effects of plyometric training on horizontal jump performance were analyzed in four studies $[48,56,58,60]$ that included both sexes and ages between 14 and 24 years old. The benefits of plyometric on horizontal jump were observed in both sexes and across the ages. Standing long jump [48,56,60], depth leap long jump [56], triple standing jump [60] and unilateral jumps with either no steps or one step taken [58] were used as tests. In the standing long jump, meaningful improvements of $7.6 \%$ were observed in senior female players after 12 weeks of plyometric training [48], a $7.6 \%$ improvement was observed in under- 16 players after six weeks of training [60], and a 3.6\% improvement was seen in 12- to 19-year-old players after 16 weeks of training [56].

These findings suggest that plyometric training positively affects horizontal jump performance, albeit with improvements lower than those recorded for vertical jump performance ( $9 \%$ to $28 \%$, as observed previously). One possible explanation for the weaker effect of plyometrics on horizontal jump performance in comparison to vertical jump performance is the specificity of the plyometric training and the optimization of the force vector and muscle stimulation during the exercises. Moreover, horizontal jumping requires both vertical and horizontal actions, and so the increased complexity of the technique may be responsible for the smaller effects of plyometric training. Still, further studies should analyze the mechanisms that lead to horizontal jump improvements, and the plyometric training program should possibly include more horizontal jumping exercises to optimize this capacity. It is possible to hypothesize that the specificity of plyometric training should be considered in the training effects, namely, to improve the direction of the forces and to translate the benefits for the field.

The type of horizontal jump should also consider since the main effect of plyometric training is to increase the SSC. If the horizontal jump does not require a countermovement action, it is expectable that the effects of plyometric training will not be so pronounced.

\subsection{Effects of Plyometric Training on Flexibility}

Flexibility is a specific action for a given joint and may have different results according to the sport [71]. The sit and reach test was used to measure the flexibility of the hip and back flexion as well as lower limb extension (hamstring) [56]. In both studies that investigated flexibility [43,56], the results revealed that plyometric training improves flexibility in under-16 women. Although few studies have assessed the impact of flexibility on volleyball players and its positive effect on vertical jump performance, the findings are ambiguous when compared to findings in studies involving other sports. One the one hand, hamstring flexibility (as measured by knee extension angle) is associated with a decrease in vertical jump height in high school students [72], while, on the other hand, flexibility is reported to be a key beneficial factor in sprinting, jumping, agility and kicking in youth football players [73]. 
Furthermore, in a study that compared the individual and combined effects of a plyometric training program and dynamic stretching on muscular strength endurance and flexibility in 45 female collegiate volleyball players, it was shown that plyometric exercises improve several functions of the nervous system and that dynamic stretches increase muscle temperature, stimulate the nervous system and improve muscle elasticity, thus increasing flexibility by $10.29 \%$ [74]. Corroborating with the previous study, Ozgul [75] found that static, dynamic and PNF flexibility exercises improve the vertical jump performance of basketball and volleyball players.

Thus, despite the findings reported in previous studies, plyometric training may be an effective way to increase athletes' flexibility, which could facilitate improvements in jump performance, agility and speed. The benefits of plyometric training can be explained by the activation of SSC that requires stretching with a contraction of the muscle, thus possibly justifying the benefits of eccentric component [76].

Future studies should consider the range of movements during plyometric training, aiming to determine which parameters may contribute to an increase in the flexibility and mobility of participants. Moreover, it is necessary for more comparative studies to be conducted with control groups aiming to determine the real benefits. Finally, an analysis of the length of fasciculus is important.

\subsection{Effects of Plyometric Training on Agility/Speed}

Few studies have considered the possibility that the agility and sprinting performance of volleyball players can be improved through plyometric training [43,46,47]. However, theoretically, plyometric training may help volleyball players develop both capacities. Sprint performance requires an explosive concentric and SSC force production in the lower limb muscles and can be benefited notably by the ability of players to use and optimize the elastic and neural properties of the SSC after plyometric training [77]. Also, agility, which is multifactorial and very complex, may be bolstered by plyometric training involving different neuromuscular adaptations (e.g., increased intermuscular coordination and firing frequencies), leading to a greater rate of force development and power output $[64,75]$.

Two studies tested the benefits of plyometric training on the agility of volleyball players in both sexes. In a study conducted over eight weeks in under-15 women, it was observed that performance at in a shuttle run $(6 \mathrm{~m} \times 6 \mathrm{~m})$ was significantly improved (by $0.7 \mathrm{~s})$ [46]. In a longer intervention (12 weeks) conducted in young adult men, it was also found that participants' agility in a $50 \mathrm{~m}$ shuttle run was meaningfully improved, as the times to complete the shuttle run decreased from 14.15 to $12.86 \mathrm{~s}$ for participants who wore a weighted vest and from 14.51 to $13.97 \mathrm{~s}$ for participants who did not wear a weighted vest [59]. Both studies confirmed the notion that plyometric training increases agility.

Plyometric training may contribute to reductions in ground contact times via increases in muscular force output and movement efficiency [78,79]. Additionally, plyometric training may improve the eccentric strength of the lower limbs, which are extremely important during the decelerations involved in short movements [78] and during the accelerations and decelerations involved in changes of direction [64]. However, such possibilities should be further researched (as should the effect of maturation) in youth players, specifically considering the relationships between maturation, the development of the central nervous system and increases in fascicle length [80].

Regarding the effect of plyometric training on sprint performance, a study involving 12 weeks of plyometric training [59] which participants completed either with or without a weighted vest showed improvements in speed during $50 \mathrm{~m}$ sprint tests for both groups. Average sprint times improved from 8.15 to $7.10 \mathrm{~s}$ for participants who wore vests and from 8.22 to $7.69 \mathrm{~s}$ for those who did not wear vests, whereas no significant change was observed in the control group [47]. In testing the effects of plyometric training on athletes' performance in a shorter sprint test $(20 \mathrm{~m})$, improvements in the time taken to complete the test from 3.8 to $3.6 \mathrm{~s}$ were observed, representing very likely benefits of $5.7 \%$.

Both studies $[46,56]$ were promising in suggesting that improvements in the sprint performance of volleyball players occur after plyometric training. Such a capacity is possibly not the most determinant or prevalent in this sport; however, it seems that the temporal sequencing of muscle activation for 
more efficient movement, preferential recruitment of fastest motor units or velocity increases in nerve conduction promoted by plyometrics successfully improves sprint performance [23]. Naturally, there is a possible link between the velocity of muscle contractions during plyometric training and the transfer of energy during sprinting [81], as well as between the type of exercise and the implications for the different phases of sprinting [77]. However, the fact that plyometric training induces repeated ballistic exercises may partially explain players' improved ability to generate explosive ground reaction forces after undergoing a plyometric training intervention [82], thus improving their acceleration during sprinting [81]. Authors should discuss the results and how they can be interpreted in the perspective of previous studies and of the working hypotheses. The findings and their implications should be discussed in the broadest context possible. Future research directions may also be highlighted.

It is important to improve future studies by adding information about the effects of plyometric training on change of direction deficits and capacity to quickly change the direction in a match.

\section{Conclusions}

The majority of the studies included $(n=13)$ focused on young players, and most of them $(n=12)$ observed only women players. However, a lack of information about the players' maturation was noticed, which could have influenced the effectiveness of the programs. The similarities between vertical jump test and the movements conducted during the training programs seem to explain the higher number of studies $(n=15)$ and the greater improvements when comparing to horizontal jumps. Nevertheless, future studies should provide more information about the characteristics of the training programs. Studies also showed that the typical plyometric training component, the SSC, promote the necessary stimulus to improve strength, as well as flexibility. This fact is justified by coordination improvements through a great muscle unit firing, in the first, and by the required lengthening movement (eccentric), in the second. Likewise, agility/speed performance was investigated in only three studies but also seems to be improved through plyometric training, possibly due to the resultant increases in muscular force output and movement efficiency, which include the faster recruitment of the motor units and increased velocity in nerve conduction. Nevertheless, more studies should be conducted to better understand the benefits of this type of training for volleyball players' overall performance.

Author Contributions: A.F.S, F.M.C. and R.L. conceived the study. A.F.S., F.M.C. and R.L. performed the search; A.F.S., F.M.C., R.L., P.T.N., T.R. and B.K. written and revised the manuscript and approved the final version.

Funding: This research received no external funding.

Conflicts of Interest: The authors declare no conflict of interest.

\section{References}

1. Polglaze, T.; Dawson, B. The physiological requirements of the positions in state league volleyball. Sports Coach 1992, 15, 32 .

2. Gabbett, T.; Georgieff, B. Physiological and anthropometric characteristics of Australian junior national, state, and novice volleyball players. J. Strength Cond. Res. 2007, 21, 902-908. [PubMed]

3. Sheppard, J.M.; Gabbett, T.J.; Stanganelli, L.R. An analysis of playing positions in elite men's volleyball: Considerations for competition demands and physiologic characteristics. J. Strength Cond. Res. 2009, 23, 1858-1866. [CrossRef] [PubMed]

4. Verhošanski, J.V.; Bobot, B. Razvoj Snage u Sportu; Partizan: Belgrade, Yugoslaviua, 1979.

5. Chu, D.A. Jumping Into Plyometrics; Human Kinetics: Champaign, IL, USA, 1998.

6. Saeed, K.K. Effect of complex trining with low-intensity loading interval on certain physical variables among volleyball infants (10-12 ages). Ovidius University Annals, Series Physical Education \& Sport/Science. Mov. Health 2013, 13, 16-21.

7. Peterson, M.D.; Alvar, B.A.; Rhea, M.R. The contribution of maximal force production to explosive movement among young collegiate athletes. J. Strength Cond. Res. 2006, 20, 867-873. [PubMed] 
8. Stone, M.H.; O’bryant, H.S.; Mccoy, L.; Coglianese, R.; Lehmkuhl, M.; Schilling, B. Power and maximum strength relationships during performance of dynamic and static weighted jumps. J. Strength Cond. Res. 2003, 17, 140-147. [PubMed]

9. Wisløff, U.; Castagna, C.; Helgerud, J.; Jones, R.; Hoff, J. Strong correlation of maximal squat strength with sprint performance and vertical jump height in elite soccer players. Br. J. Sports Med. 2004, 38, 285-288. [CrossRef] [PubMed]

10. Sheppard, J.M.; Cronin, J.B.; Gabbett, T.J.; McGuigan, M.R.; Etxebarria, N.; Newton, R.U. Relative importance of strength, power, and anthropometric measures to jump performance of elite volleyball players. J. Strength Cond. Res. 2008, 22, 758-765. [CrossRef]

11. Charoenpanicha, N.; Boonsinsukhb, R.; Sirisupc, S.; Saengsirisuwana, V. Principal component analysis identifies major muscles recruited during elite vertical jump. Age 2013, 22, 20-29. [CrossRef]

12. Martinez, D.B. Consideration for Power and Capacity in Volleyball Vertical Jump Performance. Strength Cond. J. 2017, 39, 36-48. [CrossRef]

13. Vlantes, T.G.; Readdy, T. Using Microsensor Technology to Quantify Match Demands in Collegiate Women's Volleyball. J. Strength Cond. Res. 2017, 31, 3266-3278. [CrossRef]

14. Stanganelli, L.C.R.; Dourado, A.C.; Oncken, P.; Mançan, S.; da Costa, S.C. Adaptations on jump capacity in Brazilian volleyball players prior to the under-19 World Championship. J. Strength Cond. Res. 2008, 22, 741-749. [CrossRef]

15. Lidor, R.; Ziv, G. Physical characteristics and physiological attributes of adolescent volleyball players-A Review. Pediatr. Exerc. Sci. 2010, 22, 114-134. [CrossRef]

16. Ziv, G.; Lidor, R. Vertical jump in female and male volleyball players: A review of observational and experimental studies. Scand. J. Med. Sci. Sports 2010, 20, 556-567. [CrossRef]

17. Smith, D.J.; Roberts, D.; Watson, B. Physical, physiological and performance differences between Canadian national team and universiade volleyball players. J. Sports Sci. 1992, 10, 131-138. [CrossRef]

18. Palao, J.M.; Manzanares, P.; Valadés, D. Anthropometric, physical, and age differences by the player position and the performance level in volleyball. J. Hum. Kinet 2014, 44, 223-236. [CrossRef]

19. Tsoukos, A.; Drikos, S.; Brown, L.E.; Sotiropoulos, K.; Veligekas, P.; Bogdanis, G.C. Upper and Lower Body Power are Strong Predictors for Selection of Male Junior National Volleyball Team Players. J. Strength Cond. Res. 2018. [CrossRef]

20. Wilson, J.M.; Flanagan, E.P. The role of elastic energy in activities with high force and power requirements: A brief review. J. Strength Cond. Res. 2008, 22, 1705-1715. [CrossRef] [PubMed]

21. Taube, W.; Leukel, C.; Gollhofer, A. How neurons make us jump: The neural control of stretch-shortening cycle movements. Exerc. Sport Sci. Rev. 2012, 40, 106-115. [CrossRef]

22. Ives, J.C. Motor Behavior: Connecting Mind and Body for Optimal Performance; Lippincott Williams \& Wilkins: Philadelphia, PA, USA, 2013.

23. De Villarreal, E.S.; Kellis, E.; Kraemer, W.J.; Izquierdo, M. Determining variables of plyometric training for improving vertical jump height performance: A meta-analysis. J. Strength Cond. Res. 2009, 23, 495-506. [CrossRef]

24. Davies, G.; Riemann, B.L.; Manske, R. Current concepts of plyometric exercise. Int. J. Sports Phys. Ther. 2015, 10, 760-786. [PubMed]

25. Behm, D.G.; Young, J.D.; Whitten, J.H.D.; Reid, J.C.; Quigley, P.J.; Low, J.; Li, Y.M.; Lima, C.D.; Hodgson, D.D.; Chaouachi, A. Effectiveness of traditional strength vs. power training on muscle strength, power and speed with youth: A systematic review and meta-analysis. Front. Physiol. 2017, 8, 423. [CrossRef]

26. Kubo, K.; Morimoto, M.; Komuro, T.; Yata, H.; Tsunoda, N.; Kanehisa, H.; Fukunaga, T. Effects of plyometric and weight training on muscle-tendon complex and jump performance. Sci. Sports Exerc. 2007, 39, 1801-1810. [CrossRef] [PubMed]

27. McLaughlin, E.J. A comparison between two training programs and their effects on fatigue rates in women. J. Strength Cond. Res. 2001, 15, 25-29. [CrossRef] [PubMed]

28. Pienaar, C.; Coetzee, B. Changes in selected physical, motor performance and anthropometric components of university-level rugby players after one microcycle of a combined rugby conditioning and plyometric training program. J. Strength Cond. Res. 2013, 27, 398-415. [CrossRef] [PubMed] 
29. Swanik, K.A.; Lephart, S.M.; Swanik, C.B.; Lephart, S.P.; Stone, D.A.; Fu, F.H. The effects of shoulder plyometric training on proprioception and selected muscle performance characteristics. J. Shoulder Elb. Surg. 2002, 11, 579-586. [CrossRef] [PubMed]

30. Swanik, K.A.; Thomas, S.J.; Struminger, A.H.; Bliven, K.C.H.; Kelly, J.D.; Swanik, C.B. The effect of shoulder plyometric training on amortization time and upper-extremity kinematics. J. Sport Rehabil. 2016, 25, 315-323. [CrossRef]

31. Behm, D.G. Neuromuscular implications and applications of resistance training. J. Strength Cond. Res. 1995, 9, 264-274.

32. Behm, D.G.; Faigenbaum, A.D.; Falk, B.; Klentrou, P. Canadian Society for Exercise Physiology position paper: Resistance training in children and adolescents. Appl. Physiol. Nutr. Metab. 2008, 33, 547-561. [CrossRef]

33. Cappa, D.F.; Behm, D.G. Neuromuscular characteristics of drop and hurdle jumps with different types of landings. J. Strength Cond. Res. 2013, 27, 3011-3020. [CrossRef]

34. Craig, B.W. What is the scientific basis of speed and agility? Strength Cond. J. 2004, 26, 13-14. [CrossRef]

35. Miller, J.M.; Hilbert, S.C.; Brown, L.E. Speed, quickness, and agility training for senior tennis players. Strength Cond. J. 2001, 23, 62-66. [CrossRef]

36. Young, W.B.; McDowell, M.H.; Scarlett, B.J. Specificity of sprint and agility training methods. J. Strength Cond. J. 2001, 15, 315-319.

37. Roemmich, J.N.; Rogol, A.D. Physiology of growth and development. Its relationship to performance in the young athlete. Clin. Sports Med. 1995, 14, 483-502. [PubMed]

38. Malina, R.M. Growth and maturation of young athletes: Is training for sport a factor. Sports Child. 1998, 133-161.

39. Tanner, J.M.; Whitehouse, R.H.; Marubini, E.; Resele, L.F. The adolescent growth spurt of boys and girls of the Harpenden growth study. Ann. Hum. Biol. 1976, 3, 109-126. [CrossRef] [PubMed]

40. Salci, Y.; Kentel, B.B.; Heycan, C.; Akin, S.; Korkusuz, F. Comparison of landing maneuvers between male and female college volleyball players. Clin. Biomech. 2004, 19, 622-628. [CrossRef] [PubMed]

41. Moher, D.; Shamseer, L.; Clarke, M.; Ghersi, D.; Liberati, A.; Petticrew, M.; Shekelle, P.; Stewart, L.A. Preferred reporting items for systematic review and meta-analysis protocols (PRISMA-P) 2015 statement. Syst. Rev. 2015, 4, 1. [CrossRef] [PubMed]

42. Martel, G.F.; Harmer, M.L.; Logan, J.M.; Parker, C.B. Aquatic plyometric training increases vertical jump in female volleyball players. Med. Sci. Sports Exerc. 2005, 37, 1814-1819. [CrossRef] [PubMed]

43. Turgut, E.; Colakoglu, F.F.; Guzel, N.A.; Karacan, S.; Baltaci, G. Effects of weighted versus standard jump rope training on physical fitness in adolescent female volleyball players a randomized controlled trial. Turk. J. Physiother. Rehabil. Fiz. Rehabil. 2016, 27, 108-115. [CrossRef]

44. Hewett, T.E.; Stroupe, A.L.; Nance, T.A.; Noyes, F.R. Plyometric training in female athletes. Decreased impact forces and increased hamstring torques. Am. J. Sports Med. 1996, 24, 765-773. [CrossRef] [PubMed]

45. Radu, L.E.; Făgăraş, S.; Graur, C. Lower Limb Power in Young Volleyball Players. Procedia Soc. Behav. Sci. 2015, 191, 1501-1505. [CrossRef]

46. Lehnert, M.; Lamrová, I.; Elfmark, M. Changes in speed ans strength in female volleyball players during and after a plyometric training program. Acta Univ. Palacki. Olomuc. Gymnica 2009, 39, 59-66.

47. Hrženjak, M.; Trajković, N.; Krističević, T. Effects of plyometric training on selected kinematic parameters in female volleyball players. Sport Sci. 2016, 9, 7-12.

48. Gjinovci, B.; Idrizovic, K.; Uljevic, O.; Sekulic, D. Plyometric training improves sprinting, jumping and throwing capacities of high level female volleyball players better than skill-based conditioning. J. Sports Sci. Med. 2017, 16, 527-535. [PubMed]

49. Trajkovic, N.; Kristicevic, T.; Baic, M. Effects of plyometric training on sport-specific tests in female volleyball players. Acta Kinesiol. 2016, 10, 20-24.

50. Ramlan, M.H.; Pitil, P.P.; Wahed, W.J.E. Effects of plyometric training on grass surface and concrete surface on jumping performance among volleyball athletes. Malays. J. Mov. Health Exerc. 2018, 7, 127-134. [CrossRef]

51. Çankaya, C.; Arabac1, R.; Kurt, E.; Doğan, S.; Erol, S.; Gürak, A.N.; Korkmaz, F. Examining the effects of the pliometric (jump squat) exercise on vertical jump in female volleyball players. Eur. J. Phys. Educ. Sport Sci. 2018, 5. [CrossRef] 
52. Milić, V.; Nejić, D.; Kostić, R. The effect of plyometric training on the explosive strength ok leg muscles of volleyball players on single foot and two-foot takeoff jumps. Facta Univ. Ser. Phys. Educ. Sport 2008, 6, 169-179.

53. Mroczek, D.; Superlak, E.; Konefał, M.; Maćkała, K.; Chmura, P.; Seweryniak, T.; Chmura, J. Changes in the Stiffness of Thigh Muscles in the Left and Right Limbs During Six Weeks of Plyometric Training in Volleyball Players. Pol. J. Sport Tour. 2018, 25, 20-24. [CrossRef]

54. Vassil, K.; Bazanovk, B. The effect of plyometric training program on young volleyball players in their usual training period. J. Hum. Sport Exerc. 2012, 7, S34-S40. [CrossRef]

55. Bashir, B.; SulehHayyat, F.; Shafi, S. Effect of Plyometric Training and Combination of Weight and Plyometric Training on Selected Physical Fitness Variables of College Men Volleyball Players. Online J. Multidiscip. Subj. 2018, 12, 633-637.

56. Idrizovic, K.; Gjinovci, B.; Sekulic, D.; Uljevic, O.; Joao, P.V.; Spasic, M.; Sattler, T. The Effects of 3-Month Skill-Based and Plyometric Conditioning on Fitness Parameters in Junior Female Volleyball Players. Pediatr. Exerc. Sci. 2018, 30, 353-363. [CrossRef] [PubMed]

57. Çımenlı, O.; Koç, H.; Çımenlı, F.; Kaçoğlu, C. Effect of an eight-week plyometric training on different surfaces on the jumping performance of male volleyball players. J. Phys. Educ. Sport 2016, 16, 162-169.

58. Myer, G.D.; Ford, K.R.; McLean, S.G.; Hewett, T.E. The effects of plyometric versus dynamic stabilization and balance training on lower extremity biomechanics. Am. J. Sports Med. 2006, 34, 445-455. [CrossRef] [PubMed]

59. Veličković, M.; Bojić, I.; Berić, D. The effect of programmed training on development of explosive strength in female volleyball players. Facta Univ. Ser. Phys. Educ. Sport 2017, 15, 493-499. [CrossRef]

60. Sheikh, J.A.; Hassan, M.A. Effect of plyometric training with and without weighted vest on physical variables among college men volleyball players. Int. J. Physiol. Nutr. Phys. Educ. 2018, 3, 703-706.

61. Bedoya, A.A.; Miltenberger, M.R.; Lopez, R.M. Plyometric training effects on athletic performance in youth soccer athletes: A systematic review. J. Strength Cond. Res. 2015, 29, 2351-2360. [CrossRef]

62. Stojanović, E.; Ristić, V.; McMaster, D.T.; Milanović, Z. Effect of plyometric training on vertical jump performance in female athletes: A systematic review and meta-analysis. Sports Med. 2017, 47, 975-986. [CrossRef]

63. Yoo, J.H.; Lim, B.O.; Ha, M.; Lee, S.W.; Oh, S.J.; Lee, Y.S.; Kim, J.G. A meta-analysis of the effect of neuromuscular training on the prevention of the anterior cruciate ligament injury in female athletes. Knee Surg. Sports Traumatol. Arthrosc. 2010, 18, 824-830. [CrossRef]

64. Markovic, G. Does plyometric training improve vertical jump height? A meta-analytical review. Br. J. Sports Med. 2007, 41, 349-355. [CrossRef] [PubMed]

65. Peitz, M.; Behringer, M.; Granacher, U. A systematic review on the effects of resistance and plyometric training on physical fitness in youth-What do comparative studies tell us? PLoS ONE 2018, 13, e0205525. [CrossRef]

66. Slimani, M.; Chamari, K.; Miarka, B.; Del Vecchio, F.B.; Chéour, F. Effects of plyometric training on physical fitness in team sport athletes: A systematic review. J. Hum. Kinet. 2016, 53, 231-247. [CrossRef] [PubMed]

67. Forthomme, B.; Croisier, J.; Ciccarone, G.; Crielaard, J.; Cloes, M. Factors correlated with volleyball spike velocity. Am. J. Sports Med. 2005, 33, 1513-1519. [CrossRef] [PubMed]

68. Allerheiligen, B.; Rogers, R. Plyometrics program design. Strength Cond. J. 1995, 17, 26-31. [CrossRef]

69. De Villarreal, E.S.; Requena, B.; Newton, R.U. Does plyometric training improve strength performance? A meta-analysis. J. Sci. Med. Sport 2010, 13, 513-522. [CrossRef]

70. Marques, M.A.C.; González-Badillo, J.J.; Kluka, D.A. In-Season resistance training for professional male volleyball players. Strength Cond. J. 2006, 28, 16-27. [CrossRef]

71. Voelzke, M.; Stutzig, N.; Thorhauer, H.A.; Granacher, U. Promoting lower extremity strength in elite volleyball players: Effects of two combined training methods. J. Sci. Med. Sport 2012, 15, 457-462. [CrossRef]

72. Pereira, A.; Costa, A.; Santos, P.; Figueiredo, T.; Vicente, P. Training strategy of explosive strength in young female volleyball players. Medicina 2015, 51, 126-131. [CrossRef]

73. Taware, G.B.; Bhutkar, M.V.; Surdi, A.D. A profile of fitness parameters and performance of volleyball players. J. Krishna Inst. Med Sci. Univ. 2013, 2, 48-59.

74. Skaggs, J.R.; Joiner, E.R.A.; Pace, J.L.; Atc, M.S.; Skaggs, D.L. Is Flexibility Associated with Improved Sprint and Jump Performance? Ann. Sports Med. Res. 2015, 2, 1-5. 
75. Ozgul, F. Investigating Flexibility Effects on Vertical Jump of the Adolescent Athletes. Int. J. Sports Physiol. Educ. 2018, 4, 19-21.

76. O'Sullivan, K.; McAuliffe, S.; DeBurca, N. The effects of eccentric training on lower limb flexibility: A systematic review. Br. J. Sports Med. 2012, 46, 838-845. [CrossRef]

77. Akilandeswari, S.; Pushparajan, A. Effect of Plyometric Training with Dynamic Stretching Programme on Upper Body Strength and Lower Body Strength of Female Volleyball Players. Int. J. Innov. Res. Dev. 2012, 1, 205-216.

78. Markovic, G.; Mikulic, P. Neuro-musculoskeletal and performance adaptations to lower-extremity plyometric training. Sports Med. 2010, 40, 859-895. [CrossRef]

79. Asadi, A. Plyometric type neuromuscular exercise is a treatment to postural control deficits of volleyball players: A case study. Rev. Andal. De Med. Del Deporte 2016, 9, 75-79. [CrossRef]

80. Sheppard, J.M.; Young, W.B. Agility literature review: Classifications, training and testing. J. Sports Sci. 2006, 24, 919-932. [CrossRef]

81. Young, W.B.; Mc Lean, B.; Ardagna, J. Relationship between strength qualities and sprinting performance. J. Sports Med. Phys. Fit. 1995, 35, 13-19.

82. Meylan, C.; Cronin, J.B.; Oliver, J.; Hopkins, W.; Contreras, B. The effect of maturation on adaptations to strength training and detraining in 11-15-year-olds. Scand. J. Med. Sci. Sports 2014, 24, e156-e164. [CrossRef]

(C) 2019 by the authors. Licensee MDPI, Basel, Switzerland. This article is an open access article distributed under the terms and conditions of the Creative Commons Attribution (CC BY) license (http://creativecommons.org/licenses/by/4.0/). 